щщищищищщщщ

技術功績

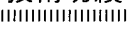

(1) 高温高効率発電プラントの 強度設計・寿命評価技術の研究と機器開発

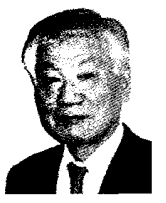

佐近淑郎*

(1949 年生)

CO2 排出量低減，発電効率の向上に高効率ガスタービン複合サイクル発 電プラント (以下 GTCC と略) が大きく貢献していることは言うまでもない. ガスタービンの高効率化は主として燃焼ガス温度の上昇による. そして, 燃 焼ガス温度の上昇は構造部材の使用条件を過酷化することに他ならない，高 温燃焼ガスに曝される空冷動静翼のメタル温度は $900^{\circ} \mathrm{C} に$ 達し, 遠心応力に 加えて冷却による急峻な温度分布による高い熱応力が発生する.この高温高 熱応力に耐えるために，動静翼には耐熱超合金，一方向凝固合金，遮熱のた めのセラミックスコーティング（TBC）等の新材料が適用される.したがっ て, GTCC の開発には，材料的にも使用条件的にも未経験の領域で信頼性 を確保するための構造強度設計・寿命評価技術が要求される。 その構築のた め, 耐熱超合金の長周期熱疲労, 異方性のある一方向凝固合金の多軸熱疲労, $\mathrm{TBC}$ の熱サイクル剥離寿命評価等に関する試験方法の考案から始め, 解析 方法, 評価方法と組み合わせて設計法を構筑してきた。これらの研究開発で 得た知昌は，1984 年に運開した入口ガス温度 $1154^{\circ} \mathrm{C}$ のTCCから, 現在 運開間近の $1600^{\circ} \mathrm{C}$ プラントに至る高温高効率化に適用されてきた。

GTCCのような新鋭火力プラントの開発と共に，長期使用されている火 力発電プラントをピークロード転用しながら安定的に運用することも重要で ある. そのため, 長期使用された蒸気タービンの劣化・余寿命の評価技術の 開発にも取り組んできた，実際の構造部材の損傷モードの評価にポイントを 置き, クリープ疲労き裂発生寿命評価法やき裂進展評価法の実機適用化研究 を展開し, 実機で重要となる長時間クリープ破断延性とクリープ疲労き裂発 生寿命低下傾向 - クリープき裂進展速度との相関性, 非線形破壊力学パラ メータの簡易評価手法等の知見を得て, 部材の余寿命評価に実用した.

また, 原子力発電に関しては, 高速增殖炉向けの高温構造設計基準, 材料 強度基準に関する研究を推進し, その成果は機械学会「発電用原子力設備規 格」にも反映されている.

*フェロー，三菱重工業（株）（テ676-8686 高砂市荒井町 2-1-1）

|IIIIIIIIIIIIIIIIIIII

技術功績

\section{(2) 数々の独創的なロボット開発と その実用化および創造教育への貢献}

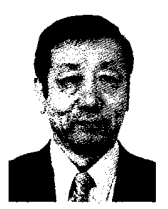

廣瀬茂男*

(1947 年生)

本研究業績は,一口で言党ば [ロボット創造学］である，その研究対象は， ヘビ型ロボット，歩行型ロボット，クローラ型ロボット，さらにそれ以外の 多様な形態の移動作業ロボットと多岐に亘っているが，それぞれ研究開発の 分野で，世界が注目する独創的成果を挙げ，またそれらを実用に結びつける 努力をし続けている.

へビ型ロボットに関しては，1971 年から実際のへビを用いた生物力学的 な研究を世界に先骒けて実施し，1972 年には世界最初のへビと同に゙原理で 推進するへビ型ロボットの蛇行推進に成功し，それらをまとめた Oxford University Press の “Biologically Inspired Robots”はその後の Biologically Inspired Roboticsの学問分野の形成に大きく貢献している. またを机以来, 40 種類以上の多様なへビ型ロボットを開発し, 世界のロボット研究を先導 して来ている. またへビ型グリッパ Soft Gripper は Under actuated gripper 研究の先駆けとなっている. 自重補償を行うへビ型マニピュレータである Float Arm は, 日産自動車（株）の組み立て工場に抢けるバランサーへと発 展し，実際に活用されている

歩行型ロボットに関しては，1978 年に世界で初めてセンサを用いた階段 昇降を行える 4 足歩行ロボットを開発し，その歩容制御について数多くの先
駆的研究成果を挙げている. 歩行ロボット研究を促進するために 4 足歩行口 ボットTITAN VIIの商品化も行い，歩行ロボットのスタンダードマシンとし て普及させている。

クローラ型ロボットに関しては, HELIOS と名付けたクローラ移動作業 ロボットの開発を続けてきている．またこの過程で, 著しく軽量で荒扎地踏 破性の高いクローラベルトをトピー工業（株）と共同開発し，その発展形で ある Survey Runner は実際に福島第一原発内部の調查に活用されている.

これら以外に, 人道的地雷探知除去作業を行うロボット開発にも取り組み, アーム搭載バギー車両の Gryphonをアンゴラなどへ供給し始めようとして いる. 水難救助作業用のロボットも開発を進め, 開発した Anchor Diver III で 2011 年の東日本大震災の際に宮城県亘理町荒浜港での行方不明者の探索 活動も行っている. さらに創造性育成教育にも大きく貢献し, 東京工業大学 機械宇宙学科の創成教育を 1990 年から大幅に刷新すると同時に，そのよう な創成教育を広く普及させるため日本機械学会主催のロボットグランプりを 1997 年から開催し，現在も組織委員長として持続的な活動を続けるなど, 市民に対する多くの啓蒙活動を続けている。

このように, 同氏の数々の独創的なロボット開発とその実用化, そして創 造教育への貢献は著しく大きい.

*フェロー, 東京工業大学大学院理工学研究科（テ 152-8552 東京都目黑区大 岡山)

IIIIIIIIIIIIIIII!I!II 技術功績

|IIIIIIIIIIIIIIIIIIIIII

（3）ディーゼルエンジン用コモンレールシステム の開発とクリーンディーゼル車普及への貢献

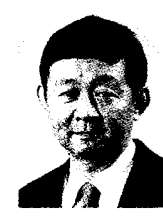

宮木正彦*

(1953 年生)

近年の地球温暖化防止の観点から，本場である欧州はもちろん，ディーゼ 儿車に対して排斥的であった日本に扔いてもクリーンディーゼル車が着目さ れるようになってきた，コモンレールシステム（CRS）は，噴射圧力およ び噴射時期を任意に制御可能であり，最適燃焼制御を実現する為に現在では 欠かすことができない技術となっている。

従来のت゙ィーゼル本は「活い「「うるさい」「走らない」イメージがあった が，CRSの登場はディーゼル車の持つ良好な燃費と力強いトルクを維持し つつ, クリーン燃焼と高い静肃性を実現できるため先述した負のイメージを 払拭することができ，まさに技術者にとってパラダイムシフトであった。

燃焼を改善するためには噴射圧力の高圧化による噴霧の微粒化が有効であ り, また特に商用車においては車両性能を 100 万 $\mathrm{km}$ を超える走行距離にわ たり長期間に保証する必要がある。これらを踏まえて，現在まで常に他社に 先んじた世界一製品の導出にチャレンジし続けてきた。

1995 年に世界で初めて量産化を果たした第 1 世代の CRS 以来, 各国の 規制強化に合わせて当時の世界最高となる噴射圧力を実現する第 2 , 第 3 世 代 CRS を顧客に供給してきた。

現在では, 乗用車用として世界最高の噴射圧力である $250 \mathrm{MPa}$ という実 に第 1 世代の 2 倍以上となる超高圧の噴射が可能な第 4 世代 CRS の開発を 行って抢り 2013 年に顧客への提供が確定している.

また制御面でも，インジェクタ内部に圧力センサを搭載し，内部の燃料の 圧力挙動から実際に噴射された燃料噴射率を推定し最適値にフィードバック する噴射特性のクローズドループ制御システムを 2012 年 6 月に世界で初め て市場投入した，これにより噴射特性の維持・改善ばかりでなく，これまで 膨大な時間が必要であった適合工数の大幅削減が可能となり，ユーザ技よび シャシメーカに大きなメリットを提供できているものと考える。

1985 年から世界に先駆けて CRS の開発に着手し，リーダとして指揮を取 ることで前述したように世界初の量産化を果たすことができた，その後も ディーゼル部門の長として CRS 開発の先頭に立って指揮し続けることで, 常に世界最高レべルの CRS を顧客に供給してきた. 今後も驰みない努力を 続けることで, より一層のディーゼル車普及を通じて地球環境の維持・改善 に貢献し続けていく所存である. 